\section{ECONOMICS}

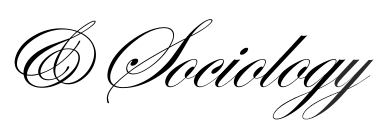

Durda, L., \& Ključnikov, A. (2019). Social networks in entrepreneurial startups development. Economics and Sociology, 12(3), 192-208. doi:10.14254/2071789X.2019/12-3/13

\title{
SOCIAL NETWORKS IN ENTREPRENEURIAL STARTUPS DEVELOPMENT
}

\author{
Lukáš Durda, \\ University of Entrepreneurship and \\ Law, Prague, Czech Republic \\ E-mail:lukas.durda@vspp.cz.

\begin{abstract}
Aleksandr Ključnikov, University of Entrepreneurship and Law, Prague, Crech Republic E-mail:kliuchnikov@gmail.com
\end{abstract}

Received: February, 2019

1st Revision: April, 2019

Accepted: September, 2019

DOI: $10.14254 / 2071-$

789X.2019/12-3/13

\begin{abstract}
The paper focuses on researching the role of social networking in the development of startup companies in the Czech Republic. The goal is to identify key groups that help startups to set up and develop, identify areas where startups get help through the social networks of their founders and/or key members, and analyze the relationship between the types of the contacts and help provided. The paper presents the results of a deep questionnaire survey of startup founders from 51 out of approximately 1450 startups in the Czech Republic. IBM SPSS Statistics 21 software and Fisher's exact test were used in two-dimensional data analysis at the significance level of 0.05 and 0.01 . The results demonstrate the use of strong and weak ties in the establishment and development of a startup business. Key groups include business partners and friends, both in terms of their utilization rates, their key role and the amount of assistance provided, and business angels in terms of fundraising, and technology and marketing advice. The importance of some weak ties does not correspond to their use (both positively and negatively). The results of the survey showed the contradictory role of incubators and accelerators. While $63 \%$ of startups used the help of business incubators, the support for building networks and links with the external environment in the incubators seems to be underestimated. Our results imply that the support programs for the startups should include the networking programs with the external parties.
\end{abstract}

Keywords: social networks, development of startup companies, strong ties, weak ties, startups

\section{Introduction}

Since the 1980s, the researchers have emphasized the importance of relationships and social networks in business processes. After some scepticism from the psychological and purely economic approaches, authors begin with the recognition of economic processes grounding in the social context (Cepel et al., 2018). They assume that the position in social networks and the quality of the relationships affects the possibility of entrepreneurs to obtain and use resources important for the initiation and growth of their businesses (Aldrich \& Zimmer, 1986). The research of the creation and use of social networking in business has got a lot of the attention in the recent years (Hoang \& Antoncic, 2003; Slotte-Kock \& Coviello, 
2010; Hoang \& Yi, 2015). Similarly, the greater attention, but rather in business than the research practice, is focused on the development of startups. New and dynamic technology-oriented companies with global ambitions come into existence, and the networking begins to play an important role in the development of these companies. Startup community, meet-ups, accelerators, presentation in front of investors and other forms of networking sites is significant for starting up a business.

Resources for the founding a new entrepreneurial unit are usually obtained from individuals based on social (family, friendship, professional) relationships with the entrepreneur (Kotha \& George, 2012). The founders use their personal network of private and business contacts to obtain resources and information that would not otherwise be available or were available at higher prices (Witt et al., 2008). The entrepreneur's role is crucial in building external relationships. The size of a company's social network at the start of doing business is largely influenced by the size of the personal network that the entrepreneur brings to the business (Lechner \& Dowling, 2003).

While social networks and the support of their members are the important factors in the quality of the business environment (Ključnikov et al., 2017), business infrastructure itself has a strong impact on networking activities and partnerships. Already at the concept stage, startups are assisted by an extensive formal network of different actors such as investors, incubators, etc. (Galkina \& Kock, 2011). Networks play a key role in the internationalization of born global firms (Andersson \& Wictor, 2003). In case of academic technological spin-off startups, networking within the so-called KIT networks (key knowledge, innovation and technology networks) is crucial already before the company is established (Pettersen \& Tobiassen, 2012). Attention is paid to individual elements of the startup ecosystem, e.g. incubators (Lin et al., 2012; Adlešič \& Slavec, 2012) or universities (Rasmussen et al., 2015).

Hoang \& Yi (2015) review study says that the networks allow getting the capital (including financial capital) from angel investors and venture capitalists, access to information and resources for internationalization, access to intangible resources, and reputation.

Startup ecosystem in investments in technological companies reached the record level in 2018, when the European software industry grew five times faster than the rest of the European economy (Atomico, 2018). While global startup ecosystems are changing in individual sub-sectors the growing sectors include fintech, cybersecurity and blockchain. The United States are losing the dominant position in these sectors, Europe is stagnating, and China is growing (Startup Genome, 2018). According to the report by Salido et al. (2013), the number of startup programs per capita was about the same in Europe and the United States. The startup's ecosystem is recently intensively developing in the Czech Republic. The offer of startup jobs as well as the demand for these job vacancies is growing in the Czech Republic and this trend can be expected to continue (StartupJobs, 2018). While the venture capital and public funds are playing the least significant role in financing of startups in the Czech Republic compared to the Visegrad 4 countries (Beauchamp \& Skala, 2017), the Czech Republic achieves the highest innovation performance (Ivanová \& Čepel, 2018) and has the most advanced innovation ecosystem (Schwab, World Economic Forum, 2018). However, an extensive network of business incubators and accelerators helps to develop new Czech and in some cases foreign startup companies, the Czech startup environment has not yet become a major concern for academics and researchers. Two extensive studies identifying the basic characteristics of Czech startups and the Czech startup ecosystem primary using the data from their own research were performed by Staszkiewicz \& Havlíková (2016), and Keiretsu Forum (2018). The official startup statistics is not currently available in the Czech Republic. Since the researchers primarily focus their studies at the startup financing (e.g. Toman \& Kousalová, 2011), the issue of networking that is not a frequent subject of the research 
activities. The only found exception was the study by Lukeš et al. (2013), in which the networking was a subject of a partial research as one of the factors affecting entry into business. Startups and social networking remain on the edge of the interest of the research of entrepreneurship in the Czech environment.

This paper presents the results of the research of the Czech startup community. The research was not focused on any specific area of business activities. The respondents mostly represent the startups operating in the field of software development, online services and ecommerce. The aim of the paper is to: 1) identify social groups that provided the startups with assistance in setting up and developing (before acquiring and after acquiring the first paying customer); 2) analyze their perceived benefits (key role); and 3) analyze the relationship between the type of contact and the assistance provided.

The first part of the paper is focused on the research of social networks in business with a focus on technology companies and startups. The next part includes the description of the used research methodology and the results of the questionnaire survey. The final part includes research findings, research limitations and recommendations for further research and the startup community.

\section{Literature review}

Semrau \& Werner (2014) recognize two basic research directions - one focused on the relational aspects, and the other on the structural characteristics. The first direction primarily focuses on exploring the role of strong and weak ties in doing business and the impact of the power of relations on their quality. Most of these researches are based on the concept of Granovetter (1973), who was first to draw the attention to the importance of the weak ties. The second research direction is the structural approach emphasizing the position in the network and the size of the network.

When examining the business networks, three layers can be distinguished. The first layer focuses on the creation of business networks, i.e. the activities that the entrepreneur performs in building, maintaining and expanding its network. The second layer focuses on the structure of the business network in a specific time and measures the result of previous activities. The third layer, which is theoretically the closest to the performance of the company, measures the economic benefits of the information and services received from the partners in the networks during a certain time (Witt, 2004). The contents, structure and dynamics belong to the often-explored characteristics of business networks, including the network of technological companies (Johannisson, 1998). Knowledge entrepreneurs are more focused on networking than the traditional entrepreneurs.

Among the most important resources that the social network acquires we can include (1) information, (2) access to finance, (3) access to information, knowledge and skills, and (4) social legitimacy (Klyver \& Hindle, 2007). Witt et al. (2008) divide four types of resources: personal contacts, knowledge and experience, physical resources and financial resources. An important benefit of the social capital is the access to other networks and contacts (Capaldo et al., 2015) and the identification of new opportunities (Stuart, Sorenson, 2005). The social networks and the links with external partners contribute to the competitiveness of companies (Škarpová \& Grosová, 2015). Pettersen \& Tobiassen (2012) distinguish such benefits of the social networks as the information, acquaintance, physical goods, financial aid, business training, personal help, moral support, legal and accounting services, creative ideas and work. The networks allow entrepreneurs to access resources at lower than market prices and to access to resources that would not otherwise be available on the market. The less the resources are available on the market, the more entrepreneurs must rely on networks and contacts (Witt et al., 2008). 
The composition of the networks and their structure changes over the time. The company should create a different network mix according to the phase of its development. An extensive use of the social networks of entrepreneurs and the creation of reputation networks are important in the early days of the company. In the later stages the company should focus on the marketing and competition networks, and lately on technology networks. In the last phase, the company reaches the limits on its relational capability and the network structure management becomes important (Lechner \& Dowling, 2003).

Social capital and networking are especially important for small technology companies and startups. One of the features of small innovative companies is their volatility and flexibility, their attempts to create new networks, to change the structure of the networks and their willingness to leave the network, in case that the network does not bring the results. Networking allows small businesses to create new forms of technological relationships, which may create new business opportunities and develop technological innovations (Mønsted, 2010).

Technology startups should obtain the resources, skills and find both internal and external partners. Technology companies are often built on innovative technological business models, that are not well documented, and as a result they lack legitimacy. Founding entrepreneurs must find a strategy to gain legitimacy (Elfring \& Hulsink, 2003).

Strong ties have a greater influence on international performance than the weak ties for high-technological small and medium-sized companies (Kenny \& Fahy, 2013). According to Romijn \& Albu (2002), strong ties may be important in some cases, in other cases, the weak ties or both types of ties can be just as important.

Networks are key to internationalization and have an important role in international business. The internationalization of growing technological firms is based on opportunities created by network partners rather than merely from managerial strategic choices. The emphasis on social networks also appears in the implementation of marketing activities (Coviello \& Munro, 1995). Building relationships are the key to entering international markets (Sigfusson \& Harris, 2012), but in certain contexts, networking may have a less important role than is usually assumed (Shirokova \& McDougall-Covin, 2012).

Evers \& O'Gorman (2011) distinguish between internationalization of vertical/horizontal and personal/business relationships. Different types of innovation are associated with different types of relationships (Partanen et al., 2014).

Startups and the startup ecosystem are terms used in a common language. Their support is considered to be an important development factor at the regional and national level. Nevertheless, these terms are not understood in a uniform way and their clear definition is missing in professional and public discourse.

While any new company may be sometimes referred to as a startup (e.g. Farlie et al., (2015, p. 9) mentions the definition of startups by Ewing Marion Kauffman Foundation"firms less than a year old with at least one employee besides the owner", it can be stated that a commonly used approach is to use some other characteristics than the length of the company's existence to define startup. According to Blank \& Dorf (2012, p. xvii), a startup "is an organization formed to search for a repeatable and scalable business model". Very wellknown is the definition by Ries (2011), according to whom "a startup is a human institution designed to deliver a new product or service under conditions of extreme uncertainty". Further, e.g., Dee et al. (2015) in their research define startups as new, innovative companies focused on rapid growth (employees, sales, customers) in finding a sustainable and scalable business model. Kollmann et al. (2016, p. 15) define startups using three basic characteristics: 1) are under 10 years old, 2) bring (highly) innovative technologies and/or business models and 3) have (strive for) significant growth in staff and/or sales. 
The relationships do exist anywhere, but specialized resources such as technical expertise and venture capital firms do not. High-resource regions offer greater opportunities for potential entrepreneurs to mobilize the necessary resources to set up a technology firm (Stuart \& Sorenson, 2003). Incubators are an important part of the startup ecosystem. According to Eveleens et al. (2017), incubators initially focused primarily on providing infrastructure, and later started to provide consulting services, and in the recent years have also largely focused on networking and interconnection. Networking should be the key for current incubators, as networked incubators are perceived as the most beneficial and successful (Hansen et al., 2000).

\section{Methodological approach}

The questionnaire survey has been a fundamental method of business network research since its inception (e.g. Greve, 1995). The founders of startups were selected as a target group of our research. The founders of the startups, selected for the research, had to meet the following criteria:

- $\quad$ to be a startup (co-)founder,

- the startup has to have at least one paying customer,

- the company must be considered a startup,

- the age of the company is limited to 7 years.

The initial version of the questionnaire was assessed by five researchers from the field of business, management and marketing (1x professor, $2 \mathrm{x}$ associate professor, $2 \mathrm{x} \mathrm{PhD}$ ) and two representatives of business incubators. At the base of the focus group comments the research team performed a partial reformulation of the questions and the categories of answers to the questions. The modified version of the questionnaire was placed in the on-line form at the Netquest.cz platform. The created online questionnaire has been verified from both content and technical point of view by two startups. The data of the research were collected from April to October, 2018.

Some respondents were selected through the cooperation with selected startup ecosystem actors. These actors verified that the selected respondent fulfills the established criteria and approached cooperating startups directly or provided the research team with the contacts of the selected startups. In one case, the given actor distributed a printed questionnaire to the cooperating startups; in the other case, the respondents were approached by a representative of the actor asking to fill in the questionnaire on-line.

Some respondents were selected and approached using the Startupjobs.cz startup database, where the startups and contacts of their representatives were searched for. Startups in Prague, Brno and Ostrava were selected for the research. When searching for a startup, the research team always was looking for the direct contact of at least one of the founders on the startup profile at Startujobs.cz or on the website. The year of the foundation of the company and the founder was found in the Trade Register (https://or.justice.cz/ias/ui/rejstrik). In case of the existence of a telephone contact, the respondent was usually approached directly. The respondent was always offered the opportunity to fill the questionnaire on-line without a personal meeting, on-line with a personal meeting, or fill in a printed version of the questionnaire at a personal meeting. All three filling options were used. During the personal meetings, the respondents were asked to provide a contact for the other startups (three contacts were obtained in this way).

Statistical analysis was performed in the IBM SPSS Statistics 21 program. Due to the size of the data sample, selection method and data distribution (not normal distribution) Fisher's exact test was used in two-dimensional data analysis. Fisher's exact test is an accurate 
test of independence and is used at small samples and for data in a $2 \times 2$ table (Hendl, 2012). The tests were performed at a significance level of 0.05 and 0.01 .

Social Network Structure (q. 1 and q. 2): Based on the research, fifteen different types of contacts that are important in setting up and developing a business were identified. Strong and weak ties, personal connections and professional and business connections were followed. The respondents were asked whether they used people from that social group in the period before or after obtaining the first paying customer. The replies were given for each of the fifteen social groups offered. Furthermore, respondents were asked to choose from the list of fifteen social groups the ones that they considered crucial for the establishment and development of a startup. They had the option of marking any number of the groups.

Social Network Contribution (q. 3): Based on the research, eleven activities in which social network is used to establish and develop startups were identified. Respondents chose from eleven activities in those they were assisted before obtaining and/or acquiring the first paying customer.

There are no official startup statistics available in the Czech Republic. One of the ways to estimate the number of startups in the Czech Republic is the StartupJobs database, resp. StartupMap (data displayed on StartupMap.cz is based on the StartupJobs database). According to StartupJobs (2018), 2250 startups used StartupJobs.cz in 2017. By the estimates of StartupJobs.cz, about 70\% of startups use their services in the Czech Republic (Hrtúsová, Novák, 2017). The founder of StartupJobs estimates that 40-50\% of the registered companies meet the characteristics of startups (according to his statement, they are "core" startups). When creating a database for the selection of the respondents, the authors of this research used the StartupJobs.cz website. Part of the companies are the internet agencies or large companies. According to these data, the number of about 1300 to 1600 startups can currently operate in the Czech Republic.

A well-known consulting company Deloitte developed a study on Czech startups for Google. The researchers contacted Ms. Popovič, the education initiative manager of the Grow with Google, who commented the study in a press release for the media (see, for example, Michl, 2018, Stalmach, 2018) for more information on the methodology and results of the research, but they were told to turn into information published in the media. According to Popovič (Štalmach, 2018), there is a "full eighth of Czech startups" in the Moravian-Silesian Region, and "behind the Moravian-Silesian 35 startups, only 17 startups have the fourth region, Central Moravia including Olomouc". From this we can conclude that according to a report for Google, about 280 startups should operate in the Czech Republic. Due to the nonpublic methodology of the report, this low figure cannot be critically assessed and interpreted.

The CzechInvest government agency operates the Czechstartups.org website (Czechstartups.org, 2018) and identifies it as the "official website about the Czech startup scene", which is available mainly for investors, startup involved persons and others interested in the Czech startup scene. There are 380 startups registered at the Czechstartups.org database. However, the website information is not up to date.

The basic characteristics of the startups involved in the research are shown in Table 1, and the characteristics of respondents according to the selected categories in Table 2.

Representativeness means the quality of survey sampling and other methodological procedures which ensure that the sample of units interviewed has a distribution of characteristics that may be deemed equal to that of the population sampled (Krejčí, 2010, p. 1012-1013), the corresponding representation of the known and, in terms of research of important characteristics (e.g. age, education), of the target population in the selection (Soukup \& Kočvarová, 2016). 
Table 1. Selected characteristics of startups involved in the research

\begin{tabular}{|c|c|c|c|c|c|c|c|}
\hline $\begin{array}{l}\text { Company } \\
\text { establishment }\end{array}$ & $\%$ & $\begin{array}{l}\text { Realization of } \\
\text { international } \\
\text { activities }\end{array}$ & $\%$ & $\begin{array}{l}\text { Number of } \\
\text { employees }\end{array}$ & $\%$ & $\begin{array}{l}\text { The character of } \\
\text { the offered product }\end{array}$ & $\begin{array}{c}\% \\
\text { (possibility } \\
\text { of multiple } \\
\text { answers) }\end{array}$ \\
\hline before 2013 & 24 & $\begin{array}{l}\text { are not } \\
\text { implemented before } \\
\text { and are planned }\end{array}$ & 27 & 0 & 6 & new & 78 \\
\hline 2013 & 8 & in foundation & 27 & $1-3$ & 20 & improved existing & 29 \\
\hline 2014 & 8 & $\begin{array}{l}1 \text { year since the } \\
\text { foundation }\end{array}$ & 10 & $4-10$ & 35 & copied and adapted & 16 \\
\hline 2015 & 16 & $\begin{array}{l}2 \text { years since the } \\
\text { foundation }\end{array}$ & 20 & $11-20$ & 27 & unspecified & 6 \\
\hline 2016 & 24 & $\begin{array}{l}3 \text { years since the } \\
\text { foundation }\end{array}$ & 8 & more than 20 & 12 & & \\
\hline 2017 & 18 & $\begin{array}{l}\text { more than three } \\
\text { years since the } \\
\text { foundation }\end{array}$ & 8 & & & & \\
\hline 2018 & 4 & & & & & & \\
\hline
\end{tabular}

Source: own compilation

Table 2. Selected socio-demographic characteristics of respondents

\begin{tabular}{llllllll}
\hline Age & $\%$ & Education & $\%$ & Position in a firm & $\%$ & Sex & $\%$ \\
\hline $20-29$ & 41 & $\begin{array}{l}\text { secondary with } \\
\text { GCSE }\end{array}$ & 33 & CEO & 73 & man & 92 \\
\hline $30-39$ & 43 & bachelor's degree & 16 & CFO, COO, etc. & 15 & woman & 8 \\
\hline $40-49$ & 16 & master's degree & 45 & others & 12 & & \\
\hline 50 and more & 0 & $\mathrm{PhD}$ & 6 & & & &
\end{tabular}

Source: own compilation

When compared to the Startup Report 2017/2018 (Keiretsu Forum, 2018), the sample can be considered as representative in terms of gender ( $91 \%$ of startup founders are males in Startup Report), in terms of education (according to Startup Report, 66\% of startup founders have a university degree and $31 \%$ secondary with GCSE). In terms of age, the respondents aged 30-39 (46\% according to Startup Report) are the same in the sample, but younger respondents (under 30) are predominant in the sample compared to Startup Report (29\%).

Due to the absence of data in the Startup Report and due to the different formulation of the questions the characteristics listed in Table 1 cannot be compared. In terms of a legal form, limited companies are more intensively represented in our research sample in comparison with the Startup Report (88\% own research, $73 \%$ Startup Report). In terms of patent registration our sample is compatible with the Startup Report (10\% own research, 13\% Startup Report).

\section{Conducting research and results}

Table 3 gives an overview of the individual questions created to explore the structure and the benefits of social networks. 
Table 3. Measurement of a structure and contribution of social networks in the questionnaire survey

\begin{tabular}{lll}
\hline Construct & Question & Operationalization \\
\hline $\begin{array}{l}\text { The social } \\
\text { network }\end{array}$ & q. 1 & Contact groups used to establish and develop a startup (q. 1a-1o) \\
structure & & \\
& & - categories of answers: \\
& - did not help \\
& - helped only in the period prior to getting the paying customer \\
& - helped only in the period after getting the paying customer \\
& - helped in the period prior to getting and after getting the paying customer
\end{tabular}

\begin{tabular}{ll} 
& $\begin{array}{l}\text { For the purposes of some analyses converted to a dichotomous variable (did not } \\
\text { help; helped) }\end{array}$ \\
\hline q. 2 & Key groups of contacts used to establish and develop a startup (q. $2 \mathrm{a}-2 \mathrm{p})$
\end{tabular}

2 categories of answers (yes or no)

The social q. 3 Activities in which assistance was provided through social network (q. 3a-3k)

network

contribution 4 categories of answers:

- nobody helped us in the above activities

- yes, only in the period prior to getting the paying customer

- yes, only in the period after getting the paying customer

- yes, help in the period prior to getting and after getting the paying customer

For the purposes of some analyses converted to a dichotomous variable (did not help; helped)

\section{Source: own compilation}

The startups used the help of the business partners (69\%), the closest family members $(66 \%)$, business incubators $(63 \%)$ and friends $(63 \%)$ to start/develop a startup more than other possibilities. On the other hand, the least used was the assistance of the competing companies (14\%), the wider family (18\%) and venture capitalists (18\%). Strong (family members, friends) as well as weak ties (business partners, the staff of incubators) belong to the group of the frequently used types of assistance. According to the respondents, the business partners and the closest family played a key role (39\% and 38\% respectively) quite often. Students' job/work colleagues (33\%) and friends (31\%) also played a key role for more than $30 \%$ of startups.

To calculate the association between a contact type and the key role of a given type of contact, question 1 was converted into a dichotomous form. In most cases, the results showed a link between the type of contact and the key role of the contact. In some cases, contacts were used frequently but were not identified as a key contact. For example, incubators staff was used in $63 \%$ of cases, but only $14 \%$ were identified as the key contacts.

The association between the type of contacts and its key role was determined by Fischer's exact test. The column percentages indicate how many startups that have marked a particular type of the used contact as the key type. Business angels, as well as students' job/job colleagues, closest family members and business partners have the highest share. The lowest share is held by people from competing companies, employees of law firms, employees of public development agencies, university staff, wider family, the staff of incubators/accelerators and employees of consulting firms (in all these cases the association was not confirmed at the significance level of 0.01 ). 
Table 4. Types of contacts used and evaluation of their importance

\section{Q. 1: Helping with establishing and developing $\quad$ Q. 2: Key role} startups

\begin{tabular}{|c|c|c|c|c|c|c|c|c|}
\hline & 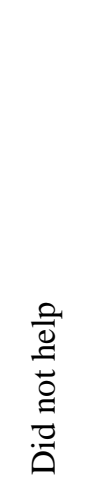 & 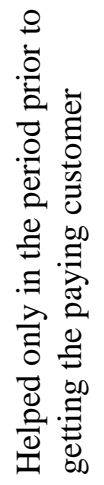 & 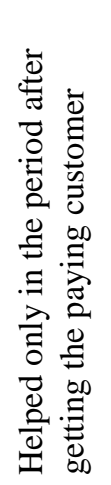 & 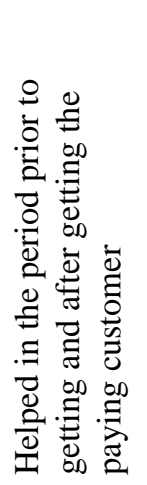 & 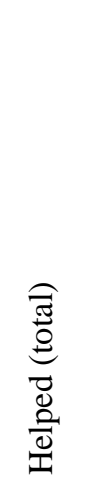 & $\stackrel{\circ}{z}$ & $\overbrace{}^{\infty}$ & 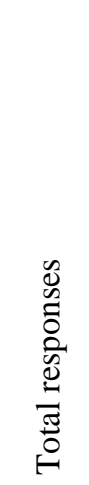 \\
\hline & $\mathrm{N}$ & $\mathrm{N}$ & $\mathrm{N}$ & $\mathrm{N}$ & $\mathrm{N}$ & $\mathrm{N}$ & $\mathrm{N}$ & $\mathrm{N}$ \\
\hline & $\%$ & $\%$ & $\%$ & $\%$ & $\%$ & $\%$ & $\%$ & $\%$ \\
\hline \multirow[t]{2}{*}{ business partners } & 15 & 4 & 11 & 19 & 34 & 30 & 19 & 49 \\
\hline & 30.6 & 8.2 & 22.4 & 38.8 & 69.4 & 61.2 & 38.8 & 100.0 \\
\hline \multirow{2}{*}{$\begin{array}{l}\text { closest family members } \\
\text { (parents, siblings, children) }\end{array}$} & 17 & 8 & 2 & 23 & 33 & 31 & 19 & 50 \\
\hline & 34.0 & 16.0 & 4.0 & 46.0 & 66.0 & 62.0 & 38.0 & 100.0 \\
\hline \multirow{2}{*}{$\begin{array}{l}\text { staff of incubators, } \\
\text { accelerators, etc. }\end{array}$} & 18 & 6 & 9 & 16 & 31 & 42 & 7 & 49 \\
\hline & 36.7 & 12.2 & 18.4 & 32.7 & 63.3 & 85.7 & 14.3 & 100.0 \\
\hline \multirow[t]{2}{*}{ friends } & 19 & 3 & 2 & 27 & 32 & 35 & 16 & 51 \\
\hline & 37.3 & 5.9 & 3.9 & 52.9 & 62.7 & 68.6 & 31.4 & 100.0 \\
\hline \multirow[t]{2}{*}{ students' job / work colleagues } & 22 & 4 & 2 & 21 & 27 & 33 & 16 & 49 \\
\hline & 44.9 & 8.2 & 4.1 & 42.9 & 55.1 & 67.3 & 32.7 & 100.0 \\
\hline \multirow[t]{2}{*}{ acquaintances } & 23 & 5 & 3 & 19 & 27 & 41 & 9 & 50 \\
\hline & 46.0 & 10.0 & 6.0 & 38.0 & 54.0 & 82.0 & 18.0 & 100.0 \\
\hline \multirow{2}{*}{$\begin{array}{l}\text { classmates (primary/secondary } \\
\text { school, university) }\end{array}$} & 27 & 4 & 3 & 14 & 21 & 39 & 9 & 48 \\
\hline & 56.3 & 8.3 & 6.3 & 29.2 & 43.8 & 81.3 & 18.8 & 100.0 \\
\hline \multirow[t]{2}{*}{ law firms / lawyers } & 31 & 5 & 6 & 9 & 20 & 50 & 1 & 51 \\
\hline & 60.8 & 9.8 & 11.8 & 17.6 & 39.2 & 98.0 & 2.0 & 100.0 \\
\hline \multirow[t]{2}{*}{ university staff } & 36 & 5 & 4 & 6 & 15 & 48 & 3 & 51 \\
\hline & 70.6 & 9.8 & 7.8 & 11.8 & 29.4 & 94.1 & 5.9 & 100.0 \\
\hline \multirow[t]{2}{*}{ business angels } & 37 & 2 & 4 & 7 & 13 & 41 & 9 & 50 \\
\hline & 74.0 & 4.0 & 8.0 & 14.0 & 26.0 & 82.0 & 18.0 & 100.0 \\
\hline \multirow[t]{2}{*}{ consulting firms } & 38 & 2 & 5 & 6 & 13 & 48 & 3 & 51 \\
\hline & 74.5 & 3.9 & 9.8 & 11.8 & 25.5 & 94.1 & 5.9 & 100.0 \\
\hline \multirow{2}{*}{$\begin{array}{l}\text { workers of public development } \\
\text { agencies }\end{array}$} & 38 & 3 & 8 & 2 & 13 & 49 & 2 & 51 \\
\hline & 74.5 & 5.9 & 15.7 & 3.9 & 25.5 & 96.1 & 3.9 & 100.0 \\
\hline \multirow[t]{2}{*}{ venture capitalists } & 41 & 2 & 3 & 4 & 9 & 46 & 4 & 50 \\
\hline & 82.0 & 4.0 & 6.0 & 8.0 & 18.0 & 92.0 & 8.0 & 100.0 \\
\hline \multirow{2}{*}{$\begin{array}{l}\text { wider family (other family } \\
\text { links) }\end{array}$} & 42 & 1 & 1 & 7 & 9 & 49 & 2 & 51 \\
\hline & 82.4 & 2.0 & 2.0 & 13.7 & 17.6 & 96.1 & 3.9 & 100.0 \\
\hline \multirow{2}{*}{$\begin{array}{l}\text { people from competing } \\
\text { companies }\end{array}$} & 43 & 3 & 2 & 2 & 7 & 50 & 0 & 50 \\
\hline & 86.0 & 6.0 & 4.0 & 4.0 & 14.0 & 100.0 & 0.0 & 100.0 \\
\hline
\end{tabular}

Source: own compilation 
Table 5. Fischer's exact test - association between contact type and the key role of a given contact type (q. 1 and 2)

\begin{tabular}{lccc}
\hline & Column & Column & $\begin{array}{c}\text { Exact Sig. } \\
(2-s i d e d)\end{array}$ \\
\hline business angels & $\mathrm{N}$ & $\%$ & $.000^{* *}$ \\
\hline students' job / work colleagues & 9 & 69.2 & $.000^{* *}$ \\
\hline closest family members (parents, siblings, children) & 16 & 59.3 & $.000^{* *}$ \\
\hline business partners & 19 & 57.6 & $.000^{* *}$ \\
\hline friends & 19 & 55.9 & $.000^{* *}$ \\
\hline venture capitalists & 16 & 50.0 & $.001^{* *}$ \\
\hline classmates (primary/secondary school, university) & 4 & 44.4 & $.000^{* *}$ \\
\hline acquaintances & 9 & 42.9 & $.002^{* *}$ \\
\hline consulting firms & 9 & 33.3 & .014 \\
\hline staff of incubators, accelerators, etc. & 3 & 23.1 & .038 \\
\hline wider family (other family links) & 7 & 22.6 & .028 \\
\hline university staff & 2 & 22.2 & .022 \\
\hline workers of public development agencies & 3 & 20.0 & .061 \\
\hline law firms / lawyers & 2 & 15.4 & .392 \\
\hline people from competing companies & 1 & 5.0 & $\mathrm{NA}$
\end{tabular}

**. Correlation is significant at the 0.01 level (2-tailed).

Source: own compilation

More than a half of the startups used each of the offered types of assistance. They used most of the help in acquiring customers $(76 \%)$, and the least in providing technology advice $(52 \%)$.

Table 6. Assistance areas (q. 3)

\begin{tabular}{|c|c|c|c|c|c|}
\hline & 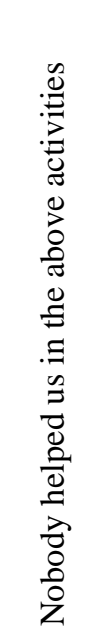 & 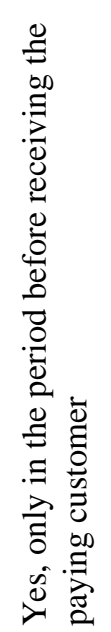 & 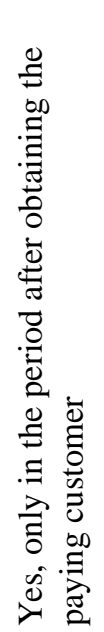 & 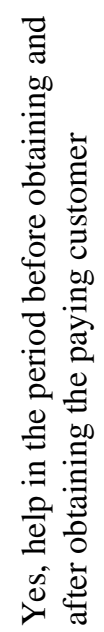 & 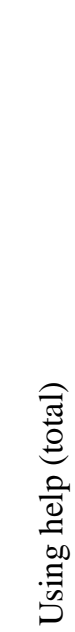 \\
\hline & $\mathrm{N}$ & $\mathrm{N}$ & $\mathrm{N}$ & $\mathrm{N}$ & $\mathrm{N}$ \\
\hline & $\%$ & $\%$ & $\%$ & $\%$ & $\%$ \\
\hline \multirow{2}{*}{ customer acquisition } & 12 & 3 & 7 & 28 & 38 \\
\hline & 24.0 & 6.0 & 14.0 & 56.0 & 76.0 \\
\hline \multirow[t]{2}{*}{ legal advice } & 15 & 3 & 7 & 26 & 36 \\
\hline & 29.4 & 5.9 & 13.7 & 51.0 & 70.6 \\
\hline \multirow[t]{2}{*}{ marketing advice } & 15 & 3 & 7 & 25 & 35 \\
\hline & 30.0 & 6.0 & 14.0 & 50.0 & 70.0 \\
\hline \multirow[t]{2}{*}{ management advice } & 16 & 4 & 9 & 22 & 35 \\
\hline & 31.4 & 7.8 & 17.6 & 43.1 & 68.6 \\
\hline \multirow[t]{2}{*}{ obtaining finance } & 16 & 10 & 7 & 18 & 35 \\
\hline & 31.4 & 19.6 & 13.7 & 35.3 & 68.6 \\
\hline product/service development & 17 & 2 & 5 & 26 & 33 \\
\hline
\end{tabular}




\begin{tabular}{lccccc}
\hline & 34.0 & 4.0 & 10.0 & 52.0 & 66.0 \\
\hline acquiring co-workers & 18 & 5 & 5 & 22 & 32 \\
\hline acquiring additional resources & 36.0 & 10.0 & 10.0 & 44.0 & 64.0 \\
\hline & 19 & 6 & 5 & 21 & 32 \\
\hline getting a reputation/legitimacy & 37.3 & 11.8 & 9.8 & 41.2 & 62.7 \\
\hline & 19 & 2 & 4 & 25 & 31 \\
\hline searching for new opportunities/markets & 38.0 & 4.0 & 8.0 & 50.0 & 62.0 \\
\hline technology consultancy & 20 & 4 & 3 & 24 & 31 \\
\hline & 39.2 & 7.8 & 5.9 & 47.1 & 60.8 \\
\hline
\end{tabular}

\section{Source: own compilation}

The association between the structure of the social network and the utilized aid was determined by Fischer's exact test. All three questions (1,2 and 3) entered as dichotomous variables. The decisive finding of the research is the existence of associations between questions 1 and 3. The test does not necessarily reflect the importance of the given group of people, because the group can assist in several areas, but not dominantly. The results of the test bring several interesting findings.

Table 7. Fisher's exact test - association between the type of contact and the help provided (Exact Sig. (2-sided))

\begin{tabular}{|c|c|c|c|c|c|c|c|c|c|c|c|c|}
\hline & & 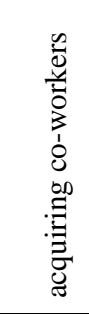 & 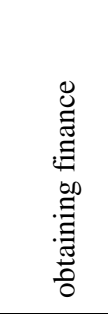 & 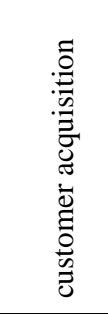 & 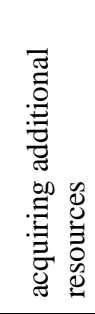 & 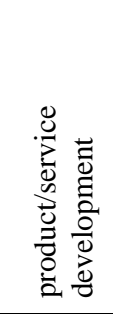 & 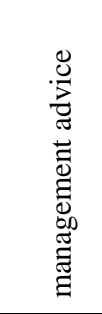 & 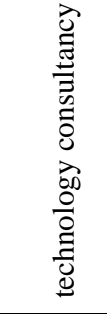 & 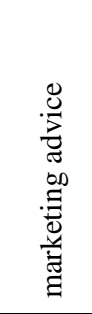 & 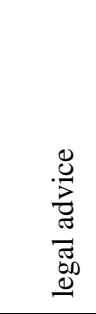 & 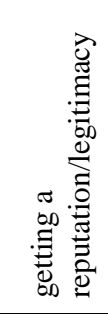 & 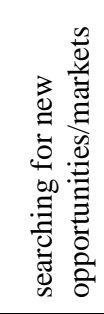 \\
\hline \multirow{2}{*}{$\begin{array}{l}\text { closest family } \\
\text { members }\end{array}$} & q. 1 & 1.000 & .757 & .480 & .352 & .523 & .533 & 1.000 & .743 & .746 & .541 & .767 \\
\hline & q. 2 & .767 & .549 & 1.000 & .366 & .351 & 1.000 & .569 & .754 & .750 & .242 & .766 \\
\hline \multirow[t]{2}{*}{ wider family } & q. 1 & 1.000 & .242 & .668 & .128 & .699 & 1.000 & .721 & .705 & .709 & .127 & 1.000 \\
\hline & q. 2 & 1.000 & 1.000 & .426 & .523 & .542 & .094 & 1.000 & .514 & .506 & 1.000 & .149 \\
\hline \multirow[t]{2}{*}{ classmates } & q. 1 & .562 & .209 & .731 & .765 & .121 & .764 & .557 & .752 & .531 & .768 & .369 \\
\hline & q. 2 & .124 & .432 & .092 & .451 & .236 & .239 & .711 & .704 & 1.000 & .455 & .451 \\
\hline \multirow{2}{*}{$\begin{array}{l}\text { students' job / work } \\
\text { colleagues }\end{array}$} & q. 1 & 1.000 & .358 & .095 & .372 & $.038 *$ & .063 & $.040 *$ & .750 & .755 & .077 & .136 \\
\hline & q. 2 & 1.000 & .520 & .725 & .346 & .350 & .324 & .368 & 1.000 & 1.000 & .343 & .754 \\
\hline \multirow[t]{2}{*}{ business partners } & q. 1 & .103 & .053 & $.000 * *$ & .059 & .178 & .520 & $.010 *$ & .315 & .177 & .210 & $.004 * *$ \\
\hline & q. 2 & .554 & .063 & $.016 *$ & .230 & .535 & 1.000 & .083 & 1.000 & .345 & .230 & .139 \\
\hline \multirow[t]{2}{*}{ university staff } & q. 1 & .523 & .333 & .304 & .123 & .746 & .510 & .760 & .107 & 1.000 & .757 & 1.000 \\
\hline & q. 2 & .544 & .543 & 1.000 & 1.000 & .264 & .543 & .103 & .211 & 1.000 & 1.000 & 1.000 \\
\hline \multirow{2}{*}{$\begin{array}{l}\text { staff of incubators, } \\
\text { accelerators, etc. }\end{array}$} & q. 1 & .127 & .217 & .325 & .242 & 1.000 & .217 & .766 & .108 & .744 & .761 & .139 \\
\hline & q. 2 & .396 & 1.000 & .662 & .407 & .686 & 1.000 & 1.000 & .662 & .392 & $.008 * *$ & 1.000 \\
\hline \multirow[t]{2}{*}{ friends } & q. 1 & .139 & 1.000 & $.017 *$ & .369 & $.000 * *$ & .228 & $.018 *$ & .528 & $.010 *$ & .135 & .774 \\
\hline & q. 2 & .351 & .746 & .292 & .117 & $.004 * *$ & .534 & 1.000 & .191 & .333 & .351 & .760 \\
\hline \multirow[t]{2}{*}{ acquaintances } & q. 1 & .228 & .548 & .331 & .081 & $.002 * *$ & .373 & .157 & .348 & .361 & .254 & .388 \\
\hline & q. 2 & .136 & .705 & .420 & .452 & .136 & .699 & 1.000 & 1.000 & .414 & .458 & 1.000 \\
\hline \multirow{2}{*}{ business angels } & q. 1 & .746 & $.004 * *$ & .480 & .320 & 1.000 & .179 & $.009 * *$ & $.043 *$ & .294 & .741 & .050 \\
\hline & q. 2 & 1.000 & $.043 *$ & .425 & .127 & .699 & .240 & $.002 * *$ & $.042 *$ & .247 & 1.000 & .067 \\
\hline \multirow[t]{2}{*}{ venture capitalists } & q. 1 & .229 & $.043 *$ & .660 & .715 & 1.000 & 1.000 & .254 & 1.000 & .247 & .720 & .285 \\
\hline & q. 2 & .288 & .292 & .566 & .284 & 1.000 & 1.000 & 1.000 & 1.000 & .302 & 1.000 & .641 \\
\hline \multirow{2}{*}{$\begin{array}{l}\text { people from } \\
\text { competing companies }\end{array}$} & q. 1 & 1.000 & 1.000 & 1.000 & 1.000 & .217 & 1.000 & .247 & .660 & .659 & .398 & .100 \\
\hline & q. 2 & NA & NA & NA & NA & NA & NA & NA & NA & NA & NA & NA \\
\hline workers of public & q. 1 & .746 & .185 & .147 & $.018 *$ & 1.000 & $.004 * *$ & 1.000 & .728 & .076 & .742 & .204 \\
\hline
\end{tabular}




\begin{tabular}{|c|c|c|c|c|c|c|c|c|c|c|c|c|}
\hline development a & q. 2 & 1.000 & 1.000 & 1.000 & .523 & .111 & 1.000 & 1.000 & 1.000 & 1.000 & 1.000 & .514 \\
\hline \multirow[t]{2}{*}{ consulting firms } & q. 1 & 1.000 & 1.000 & .480 & .323 & .173 & .730 & .526 & .728 & .730 & .095 & .204 \\
\hline & q. 2 & .291 & 1.000 & 1.000 & .285 & 1.000 & 1.000 & .602 & 1.000 & 1.000 & 1.000 & .271 \\
\hline \multirow[t]{2}{*}{ law firms / lawyers } & q. 1 & .237 & .064 & .317 & .554 & .365 & .221 & .159 & .754 & $.026 *$ & .774 & .381 \\
\hline & q. 2 & 1.000 & 1.000 & 1.000 & 1.000 & 1.000 & 1.000 & .480 & .300 & 1.000 & .380 & .392 \\
\hline
\end{tabular}

*. Correlation is significant at the 0.05 level (2-tailed).

**. Correlation is significant at the 0.01 level (2-tailed).

Source: own compilation

The results of the research confirm the important role of business partners and angel investors. In case of angel investors, the research results indicate an existence of the association in providing technology and marketing advice in addition to financial assistance. In all these cases, associations have been demonstrated both for the use of angel investors (question 1) and their key role (question 2). The research results confirm that, in the early stages of the startup, in addition to the capital the angel investors contribute with their experience and knowledge. The benefits of technology advices points to the experience of the investors in this industry. The angel investor in the field of IT is not just a provider of capital, but a partner with the experience gained from the other areas of business and seeking investment opportunities. In case of the business partners, the significance of their role was confirmed mainly in relation to the acquisition of customers (for question 1, the correlation is significant at 0.01 level, for question 2 at 0.05 level). These results demonstrate an important role of external partners for the startups.

The further finding is that friends play a key role in product and/or service development. The association has been proven for both questions, and the correlations are significant at 0.01 level.

\section{Discussion}

The results of the recently published studies demonstrate the importance of the use of strong and weak ties in developing business networks in the early stages of doing business (Elfring \& Hulsing, 2007). The ways of their usage depend on the initial conditions and other processes following the startup.

According to Partanen et al. (2014), the role of the social capital and networking in acquiring the resources in the early stages of company development is not often in the focus of the research activities. Their study demonstrates the benefits of each type of the contact for specific activities. The number of the available resources usually grows with the number of the used contacts. One type of social connections can be often used in different ways (e.g. friends can provide moral and material support, work and non-work counselling) (Adler \& Kwon, 2002) and can provide different resources and contribute to the company's survival and success (Partanen et al., 2014). According to Shaw (2006), the networks allow the early stage startups to obtain resources at a lower cost, and in subsequent stages to obtain resources that are not available through market mechanisms. The social capital has a potential value because it provides actors with the opportunity to access information and resources in their social networks (Maurer \& Ebers, 2006). Our research results correspond to the requirement to explore what entrepreneurs can gain, not just how they are linked.

However, the increasing attention is being paid to the research on entrepreneurial ecosystems, it usually lacks an analytical framework, does not sufficiently involve a network theory, and it is unclear what institutions have an impact on the structure and performance of the entrepreneurial ecosystem. The studies usually focus on only one ecosystem and do not examine its dynamics (Alvedalen \& Boschma, 2017). 
Business incubators provide new businesses with credibility and help them to gain support and networking. Providing support networks increases business satisfaction with the incubators (Tötterman \& Sten, 2005). It can be assumed that the support for building networks and links with the external environment may be missing from the questionnaire survey.

The questionnaire survey was conducted on a limited sample of startups. Approximately every fortieth startup in the Czech Republic was involved in the selection. Based on previous studies on Czech startups on a set of about 100 startups and based on data collection experience, the authors believe that it is not possible to provide the data from more than 150 startups. One of the possibilities of obtaining the data from a larger number of startups representatives is to carry out surveys in several countries (e. g. similar to Beauchamp \& Skala, 2017, at startups from the Visegrad Group).

This study has some limitations. Given the relative homogeneity of the research population in terms of company size, age, internationalization, it was not possible to analyze data in relation to the performance and results of startups. An important direction of the further research may, therefore, explore the contribution of networks to the success of startup companies. Furthermore, it would be advisable to carry out longitudinal research, since even being aware of its difficulty, the results may define how the transformation of the structure of the networks is performed.

\section{Conclusion}

Startups belong to the most vulnerable group of small and medium-sized enterprises. Most of the researchers assume that the position in social networks and the quality of the relationships affect the possibility of entrepreneurs to obtain and use resources important for the initiation and growth of a business.

The goal of this paper was to identify groups that have provided startups with assistance in setting up and developing before acquiring and after acquiring the first paying customer, to analyse their perceived benefits (key role) and to analyse the relationship between the type of contact and the assistance provided.

The results of a deep questionnaire survey of startup founders from 51 out of approximately 1450 startups in the Czech Republic were analysed with the use of IBM SPSS Statistics 21 software and Fisher's exact test in two-dimensional data analysis at a significance level of 0.05 and 0.01 .

The results demonstrate the use of strong and weak ties in the establishment and development of a startup business. Key and most useful groups of contacts include friends (customer acquisition, product/service development, technology and legal advice), business angles (fundraising, technology advice, marketing advice) and business partners (customer acquisition, technology advice, and new opportunities search). The importance of some weak ties does not correspond to their use (both positively and negatively).

The results of the research showed the contradictory role of incubators and accelerators. While $63 \%$ of startups used the help of business incubators, the support for building networks and links with the external environment in the incubators seems to be underestimated. From this point of view, incubators and accelerators can be advised to consider offering programs that would better meet startup needs and increase their perceived benefits, especially towards networking with external partners. It has to be said that this step is very difficult with regard to the different needs of individual startups as well as personal and organizational possibilities of incubators/accelerators.

The nature of the research and its focus did not (and did not seek to) identify strategies and approaches to the use of networks and social capital in relation to the success of startups. 
The results of our research do not bring an exact answer on the question how to "build and use social networks properly". However, it can be clearly stated that it is "important to build and use them". Startup founders are aware of this and proceed accordingly.

\section{References}

Adler, P. S., \& Kwon, S. W. (2002). Social capital: Prospects for a new concept. The Academy of Management Review, 27(1), 17-40. doi: 10.2307/4134367

Adlešič, R. V., \& Slavec, A. (2012). Social capital and business incubators performance: Testing the structural model. Economic and Business Review, 14(3), 201-222.

Aldrich, H., \& Zimmer, C. (1986). Entrepreneurship through social networks. In: Sexton, D. L., \& Smilor, R. W. (Eds.). The Art and Science of Entrepreneurship, Cambridge: Ballinger Publishing Company, 3-23.

Alvedalen, J., \& Boschma, R. (2017). A critical review of entrepreneurial ecosystems research: towards a future research agenda. European Planning Studies, 25(6), 887-903. doi: 10.1080/09654313.2017.1299694

Andersson, S., \& Wictor, I. (2003). Innovative internationalisation in new firms: Born globals - the Swedish case. Journal of International Entrepreneurship, 1(3), 249-275. doi: 10.1023/A:1024110806241

Atomico (2018). The State of European Tech 2018. London: Atomico. Retrieved January 8, 2019, from https://2018.stateofeuropeantech.com/chapter/state-european-tech-2018/

Beauchamp, M., \& Skala, A. (2017). Visegrad Startup Report 2016/2017. Retrieved January 3, 2018, from https://s3.eu-central-1.amazonaws.com/uploads.mangoweb.org/sharedprod/aspeninstitutece.org/uploads/2017/06/Visegrad-Startup-Report-5.pdf

Blank, S., \& Dorf, B. (2012). The Startup owner's manual: The step-by-step guide for building a great company. Pescadero: K \& S Ranch.

Capaldo, G., Fontes, M., Cannavacciuolo, L., Rippa, P., \& Sousa, C. (2015). Networks mobilized to access key resources at early stages of biotech firms: A comparative analysis in two moderately innovative countries. European Planning Studies, 23(7), 1381-1400. doi: 10.1080/09654313.2014.934206

Cepel, M., Stasiukynas, A., Kotaskova, A., \& Dvorsky, J. (2018). Business environment quality index in the SME segment. Journal of Competitiveness, 10(2), 21-40. doi: 10.7441/joc.2018.02.02

Coviello, N. E., \& Munro, H. J. (1995). Growing the entrepreneurial firm: networking for international market development. European Journal of Marketing, 29(7), 49-61. doi: 10.1108/03090569510095008

Czechstartups.org (2018). Praha: CzechInvest, Retrieved January 5, 2019, from http://www.czechstartups.org

Dee, N., Gill, D., Weinberg, C., \& McTavish, S. (2015). Startup Support Programmes. What's the Difference?. Nesta, February 2015. Retrieved March 27, 2019, from https://media.nesta.org.uk/documents/whats_the_diff_wv.pdf

Elfring, T., \& Hulsink, W. (2003). Networks in Entrepreneurship: The Case of Hightechnology Firms. Small Business Economics, 21(4), 409-422. doi: 10.1023/A:1026180418357

Elfring, T., \& Hulsink, W. (2007). Networking by Entrepreneurs: Patterns of Tie-Formation in Emerging Organizations. Organization Studies, 28(12), 1849-1872. doi: $10.1177 / 0170840607078719$

Eveleens, C. P., van Rijnsoever, F. J., \& Niesten, E. M. M. I. (2017). How network-based incubation helps start-up performance: a systematic review against the background of 
management theories. The Journal of Technology Transfer, 42(3), 676-713. doi: 10.1007/s10961-016-9510-7

Evers, N., \& O'Gorman, C. (2011). Improvised Internationalization in New Ventures: The Role of Prior Knowledge and Networks. Entrepreneurship \& Regional Development, 23(7-8), 549-574. doi: 10.1080/08985621003690299

Fairlie, R. W., Morelix, A., Reedy, E. J., \& Russell, J. (2015). The Kauffman index 2015: StartupActivity / National trends. Ewing Marion Kauffman Foundation. Retrieved March 2, 2019, from https://www.kauffman.org/ /media/kauffman_org/research\%20reports\%20and\%20cove rs/2015/05/kauffman_index_startup_activity_national_trends_2015.pdf

Galkina, T., \& Kock, S. (2011). The influence of entrepreneurial infrastructure on entrepreneur networking: a comparative case study of Russian and Finnish founding teams. International Journal of Entrepreneurship and Small Business, 13(3), 238-254. doi: 10.1504/IJESB.2011.041659

Granovetter, M. S. (1973). The strength of weak ties. American Journal of Sociology, 78(6), 1360-1380.

Greve, A. (1995). Networks and entrepreneurship - an analysis of social relations, occupational background, and use of contacts during the establishment process. Scandinavian Journal of Management, 11(1), 1-24.

Hansen, M. T., Chesbrough, H., Sull, D., \& Nohria, N. (2000). Networked incubators. Hothouses of the new economy. Harvard Business Review, 78(5), 74-84.

Hendl, J. (2012). Přehled statistických metod: analýza a metaanalýza dat. Praha: Portál.

Hoang, H., \& Antoncic, B. (2003). Network-based research in entrepreneurship: A critical review. Journal of Business Venturing, 18(2), 165-187. doi: 10.1016/S08839026(02)00081-2

Hoang, H., \& Yi, A. (2015). Network-based research in entrepreneurship: a decade in review. Foundations in trends in entrepreneurship,11(1), 1-54. Hanover: now Publishers. doi: $10.1561 / 0300000052$

Hrtúsová, T., \& Novák, R. (2017). Start-upy v ČR: State of Play. EU office / Knowledge Centre, Česká spořitelna. Retrieved January 8, 2019, from https://www.investicniweb.cz/Files/startupy-v-cr/

Ivanová, E., \& Čepel M. (2018). The Impact of Innovation Performance on the Competitiveness of the Visegrad 4 Countries. Journal of Competitiveness, 10(1), 54-72. doi: 10.7441/joc.2018.01.04

Johannisson, B. (1998). Personal networks in emerging knowledge-based firms: spatial and functional patterns. Entrepreneurship \& Regional Development, 10(4), 297-312. doi: 10.1080/08985629800000017

Keiretsu Forum (2018). Startup Report 2017/2018. Prague: Keiretsu Forum Prague SE.

Kenny, B., \& Fahy, J. (2013). The Role of Tie Strength, Relational Capability and Trust in the International Performance of High Tech SMEs. IMP Journal, 7(3), 188-203.

Ključnikov, A., Kozubíková, L., \& Sopková, G. (2017). The Payment Discipline of Small and Medium-sized Enterprises. Journal of Competitiveness, Vol. 9, Issue 2, pp. 45-61. doi: 10.7441/joc.2017.02.04

Klyver, K., \& Hindle, K. (2007). The Role of Social Networks At Different Stages of Business Formation. Small Business Research, 15(1), 22-38. doi: 10.1080/13215906.2007.11005830

Kollmann, T., Hensellek, S., \& Kensbock, J. (2016). European Startup Monitor 2016. German Startups Association. Retrieved January 3, 2017, from http://europeanstartupmonitor.com/fileadmin/esm_2016/report/ESM_2016.pdf 
Kotha, R., \& George, G. (2012). Friends, Family, or Fools: Entrepreneur Experience and its Implications for Equity Distribution and Resource Mobilization. Journal of Business Venturing, 27(5), 525-543. doi: 10.1016/j.jbusvent.2012.02.001

Krejčí, J. (2010). Approaching Quality in Survey Research: Towards a Comprehensive Perspective. Sociologický Časopis / Czech Sociological Review, 46(6), 1011-1033. Retrieved December 12, 2018 from http://www.jstor.org/stable/41132928

Lechner, Ch., \& Dowling, M. (2003). Firm networks: external relationships as sources for the growth and competitiveness of entrepreneurial firms. Entrepreneurship \& Regional Development, 15(1), 1-26. doi: 10.1080/08985620210159220

Lin, D., Wood, L. Ch., \& Lu, Q. (2012). Improving business incubator service performance in China: the role of networking resources and capabilities. The Service Industries Journal, 32(13), 2091-2114. doi: 10.1080/02642069.2011.582498

Lukeš, M., Zouhar, J., Jakl, M., \& Očko, P. (2013). Faktory ovlivňující vstup do podnikání: začínající podnikatelé v České republice. Politická ekonomie, 61(2), 229-247. doi: 10.18267/j.polek.896

Maurer, I., \& Ebers, M. (2006). Dynamics of Social Capital and Their Performance Implications: Lessons from Biotechnology Start-ups. Administrative Science Quarterly, 51(2), 262-292. doi: 10.2189/asqu.51.2.262

Michl, P. (2018). Google spouští portál Startup with Google v češtině. Chce, aby díky němu vznikalo víc startupů i mimo Prahu. Marketing Journal, June 25, 2018. Retrieved January 5, 2019, from https://www.m-journal.cz/cs/aktuality/google-spousti-portalstartup-with-google-v-cestine--chce--aby-diky-nemu-vznikalo-vic-startupu-i-mimoprahu_s288x13789.html

Mønsted, M. (2010). Networking and Entrepreneurship in Small High-Tech European Firms: An Empirical Study. International Journal of Management, 27(1), 16-30.

Partanen, J., Chetty, S. K., \& Rajala, A. (2014). Innovation Types and Network Relationships. Entrepreneurship: Theory and Practice, 38(5), 1027-1055. doi: 10.1111/j.15406520.2011.00474.x

Pettersen, I. B., \& Tobiassen, A. E. (2012). Are born globals really born globals? The case of academic spin-offs with long development periods. Journal of International Entrepreneurship, 10(2), 117-141. doi: 10.1007/s10843-012-0086-5

Rasmussen, E., Mosey, S., \& Wright, M. (2015). The transformation of network ties to develop entrepreneurial competencies for university spin-offs. Entrepreneurship \& Regional Development, 27(7-8), 430-457. doi: 10.1080/08985626.2015.1070536

Ries, E. (2011). The Lean Startup: How Today's Entrepreneurs Use Continuous Innovation to Create Radically Successful Businesses. New York: Crown Business.

Romijn, H., \& Albu, M. (2002). Innovation, Networking and Proximity: Lessons from Small High Technology Firms in the UK. Regional Studies, 36(1), 81-86. doi: 10.1080/00343400120099889

Salido, E., Sabás, M., \& Freixas, P. (2013). The accelerator and incubator ecosystem in Europe. Brussel: European Commission, Telefónica. Retrieved January 8, 2019, from https://lisboncouncil.net/component/downloads/?id=897

Semrau, T., \& Werner, A. (2014). How Exactly Do Network Relationships Pay Off? The Effects of Network Size and Relationship Quality on Access to Start-Up Resources. Entrepreneurship: Theory and Practice, 38(3), 501-525. doi: 10.1111/etap.12011

Shaw, E. (2006). Small Firm Networking: An Insight into Contents and Motivating Factors. International Small Business Journal, 24(1), 5-29. doi: 10.1177/0266242606059777

Shirokova, G., \& McDougall-Covin, P. (2012). The role of social networks and institutions in the internationalization of Russian entrepreneurial firms: Do they matter?. Journal of International Entrepreneurship, 10(3), 177-199. doi: 10.1007/s10843-012-0091-8 
Schwab, K., \& World Economic Forum (2018). The Global Competitiveness Report 2018. Geneve: World Ecomomic Forum. Retrieved January 8, 2019, from https://www.weforum.org/reports/the-global-competitveness-report-2018

Sigfusson, T., \& Harris, S. (2012). The relationship formation paths of international entrepreneurs. Journal of International Entrepreneurship, 10(4), 325-349.

Slotte-Kock, S., \& Coviello, N. (2010). Entrepreneurship Research on Network Processes: A Review and Ways Forward. Entrepreneurship: Theory and Practice, 34(1), 31-57. doi: 10.1111/j.1540-6520.2009.00311.x

Soukup, P., \& Kočvarová, I. (2016). Velikost a reprezentativita výběrového souboru v kvantitativně orientovaném pedagogickém výzkumu. Pedagogická orientace, 26(3), 512-536. doi: 10.5817/PedOr2016-3-512

Startup Genome (2018). Global Startup Ecosystem Report 2018. Succeeding in the New Era of Technology. Startup Genome. Retrieved January 8, 2019, from https://startupgenome.com/reports/global-startup-ecosystem-report-2018

StartupJobs (2018). StartupJobs - Startup Report 2017. Startupedia. Retrieved January 8, 2019, from https://www.startupjobs.cz/upload/press/startupjobs-startup-report-2017.pdf

Staszkiewicz, M., \& Havlíková, D. (2016). České startupy 2016. Prague: Aspen Institute Prague. Retrieved January 3, 2018, from https://s3.eu-central1.amazonaws.com/uploads.mangoweb.org/sharedprod/aspeninstitutece.org/uploads/images_upload/files/Ceske_startupy_2016.pdf

Stuart, T. E., \& Sorenson, O. (2005). Social Networks and Entrepreneurship. In: Alvarez, S. A., Agarwal, R., \& Sorenson, O. (Eds.). Handbook of Entrepreneurship Research. New York: Springer, 233-252.

Stuart, T. E., \& Sorenson, O. (2003). The geography of opportunity: spatial heterogeneity in founding rates and the performance of biotechnology firms. Research Policy, 32(2), 229-253. doi: 10.1016/S0048-7333(02)00098-7

Škarpová L., \& Grosová S. (2015). The Application of Business Network Approach for Small and Medium Enterprises (SME) with regard to their Buying Behavior. Journal of Competitiveness, 7(3), 62-74. doi: 10.7441/joc.2015.03.05

Štalmach, D. (2018). Moravskoslezský kraj má málo inženýrů a vědců, zaostává v inovacích. IDnes.cz [online]. September 25, 2018. Retrieved January 5, 2019, from https://www.idnes.cz/ostrava/zpravy/inovace-veda-vyzkum-technicke-vzdelani-trhprace-moravskoslezsky-kraj.A180925_429093_ostrava-zpravy_woj

Toman, P., \& Kousalová, L. (2011). Státní podpora venture kapitálu v České republice. Journal of Competitiveness, 3(1), 116-130.

Tötterman, H., \& Sten, J. (2005). Start-ups: Business Incubation and Social Capital. International Small Business Journal, 23(5), 487-511. doi: 10.1177/0266242605055909

Witt, P. (2004). Entrepreneurs' networks and the success of start-ups, Entrepreneurship \& Regional Development, 16(5), 391-412. doi: 10.1080/0898562042000188423

Witt, P., Schroeter, A., \& Merz, Ch. (2008). Entrepreneurial resource acquisition via personal networks: an empirical study of German start-ups. Service Industries Journal, 28(7), 953-971. doi: 10.1080/02642060701846846 